\title{
Heavy Metal Contents and Accumulation Characteristic of Dominant Plants in Tin Mining Wasteland of Gejiu city, Yunnan,China
}

\author{
Song Xiang-bin ${ }^{1}$, Li Gui-xiang ${ }^{2, ~}{ }^{*}$, Fang Xiang-jing ${ }^{2}$, Shao Jin-ping ${ }^{2}$, He Li- \\ ping $^{2}, \mathrm{Bi} \mathrm{Bo}^{2}$ \\ ${ }^{1}$ Southwest Forestry University, Environmental Science and Engineering, 650224, Kunm- \\ ing,China; ${ }^{2}$.Yunnan Academy of Forestry, 650201, Kunming,China
}

KEYWORD: Wasteland; Heavy metal; Dominant species

ABSTRACT: Land contaminated by high levels of heavy metals in Tin mining wasteland is urgent to be remediated.To find out the tolerant plants which can adapt to the local climate and the soil conditions is thesystem restoration of the area. Results showed that the average content of soil heavy metals of $\mathrm{Mn}, \mathrm{Cu}, \mathrm{Cd}$ and $\mathrm{Zn}$ were $5733.8702 \mathrm{mg} / \mathrm{kg}, 2250.7998 \mathrm{mg} / \mathrm{kg}, 1974.8084 \mathrm{mg} / \mathrm{kg}$ and $17.0273 \mathrm{mg} / \mathrm{kg}$, the soil was alkaline soil in the wasteland. It was found that the 12 wild plants had different abilities of uptake and accumulation of $\mathrm{Mn}, \mathrm{Cu}, \mathrm{Cd}$ and $\mathrm{Zn}$. The bioaccumulation factor (BCF) of all the dominant plants were less than 1, only Polygonum capitatum and Hippochaete debilis of BCF were relatively large, and the biological transfer factor (BTF) of Polygonum capitatum to $\mathrm{Mn}$ and $\mathrm{Zn}$ were more than 1, the BTF of Hippoc premise and foundation of vegetation reconstruction.Analyzed the amount of heavy metals, and the enrichment and transporting features of heavy metals, such as $\mathrm{Mn}, \mathrm{Cu}, \mathrm{Cd}$ and $\mathrm{Zn}$, in the dominant species in the district, and then we select the pioneer plants for ecohaete debilis to $\mathrm{Cd}$ and $\mathrm{Zn}$ were more than 1 . In general, the results indicate that the two plants had strong capability of BCF and BTF to heavy metals. Apart from two plants, other 10 dominant plants had a better tolerance in metal pollution in mining area, and they can be used as pioneer plants of ecological rehabilitation in tin mining wasteland.

\section{INTRODUCTION}

With the rapid development of the mining industry, the problem of heavy metal pollution in the wasteland has become one of the hot issues of environmental pollution. This kind of contamination in the soil long residual period, the soil microorganisms can not be broken down, these pollute the groundwater, inhibit the growth and development of plants, more serious is that after the accumulation of edible part in crops passed to humans through the food chain, causing heavy metal poisoning, a direct threat to human health and safety(Yang et al. 2004, Yue2000). According to statistics, China's mining wasteland area has reached 40,000 hectare, and annual at a speed of 200 hectare growth(China Environmental Protection Agency 2000). Mining activities seriously interfere with and over the ecosystem self-recovery tolerance limits, if let the mining wastelands rely on natural succession recovery, it may take 100 to 10,000 years(Bradshaw1997). So the ecological restoration in mining wasteland has become a top priority.

Phytoremediation is the use of plant absorption and fixation of heavy metals in the soil, thereby to repair contaminated soil green engineering technology, which is based on the restoration of heavy metals have a high tolerance, high enrichment of hyperaccumulator plants. Hyperaccumulator as an emerging green technology, has the characteristics of efficient, economic and ecological coordination and becomes a hot area of current research, and it is widely used in the field of remediation of heavy metal pollution for its thoroughness of restoration and environment friendly characteristics. Therefore, it is the premise and foundation of vegetation reconstruction to find out tolerant plants which can adapt to the local climate and the soil conditions.

Gejiu is a super large tin copper polymetallic mining area, the cumulative proven reserves of nonferrous metals 4.76 million $t$, which the tin reserves of 1.72 million $t$, mining resulted in large areas of wasteland in Gejiu(Gan et al. 2008, Zhang et al. 2010). Therefore, the study by sampling wasteland soil and dominant plant from Niubahuang, Kafang and Southern in tin mine of Gejiu, and by analyzing the content of heavy metal in soil and plant, the accumulation and migration of heavy 
metal in plant, this research will provide scientific evidence for ecological restoration and revegetation in tin mining wasteland in Gejiu.

\section{MATERIALS AND METHODS}

\section{Brief introduction of research area}

The research site is in Gejiu County city, Honghe prefecture of Yunnan province,southern China, across the east longitude $103^{\circ} 07^{\prime} 28^{\prime \prime} \sim 103^{\circ} 09^{\prime} 14^{\prime \prime}$, north latitude $23^{\circ} 18^{\prime} 56^{\prime \prime} \sim 23^{\circ} 21^{\prime} 39^{\prime \prime}$. Gejiu is the production of tin-based and produce lead, zinc, copper and other non-ferrous metals metallurgy industrial city, is world-renowned "tin can". There are big differences between the elevation height, with significant vertical climate vertical distribution, belonging to 5 kinds of climate zones (north tropics, south Asian tropical, subtropical, tropical and north and south temperate). The annual sunshine short, small temperature difference, long frost free period, dry and rainy seasons clear, mild climate, the average annual sunshine 1986.6h, with an average annual temperature of 16.4 degrees, the year rainfall $890 \mathrm{~mm}$.

\section{Research methods}

\section{Sample Collection}

Collection of Soil samples: Field investigation and sample collection were done in 2014 June in three Tin mining wasteland, Niubahuang, Kafang and Southern of Gejiu City. According to the wasteland area and the terrain characteristics, respectively by the methods of "S" distribution and zonal distribution, gathering $0 \sim 20 \mathrm{~cm}$ topsoil, samples of each of plurality of points by mixing soil samples were collected using quartation, whichever weighing about $1 \mathrm{~kg}$, into the ziplock, label, back to the lab.

Collection of Plant samples:Selection of high frequency distribution, growth better, a large number of plants were randomly sampled, including natural settled the dominant plants and artificial large area planted of economic crops in the three mining wastelands. The plants of 5 to 10 plants were collected from different parts of the plant, such as root, stem, leaf and fruit, etc, form a composite sample(after preparation, the general, at least 20-50g dry weight of the sample),

aboveground parts and underground parts to be separated, try to maintain the integrity of plants. Put the collection of samples into valve bag, and labeled, indicating the No., collection sites, name of plants collection, etc.

\section{Pretreatment of samples}

Pretreatment of soil samples:Soil samples were placed the dry soil shelf of National plateau Wetlands Research Center of Southwest Forestry University, by flipping, tick miscellaneous,etc, after being air dried soil samples and fully grinding to make it all over 100 mesh nylon sieve. Sieved samples were mixed well by quartation, bagged, indicating the No.,labeled, pended the determination.

Pretreatment of plant samples:Plant samples woody plants by the roots, stems, leaves separated, herbs separated by aboveground parts and underground parts. The plant samples were washed with water and then to clean them three times using deionized water, placed to dry naturally. To chop them by stainless steel knife after dried, in the drying chamber firstly at $105^{\circ} \mathrm{C}$ fixing $30 \mathrm{~min}$, after at $70^{\circ} \mathrm{C}$ in drying to constant and then were milled through a 60 mesh nylon sieve.Sieving samples are mixed evenly, then packed into sealed bags labeled save and set aside. 
Table1 The analysis of the characteristics of heavy metal content of wasteland soil

\begin{tabular}{|c|c|c|c|c|c|}
\hline \multirow{2}{*}{ Mining wasteland } & \multirow{2}{*}{$\mathrm{pH}$} & $\mathrm{Mn}$ & $\mathrm{Cu}$ & $\mathrm{Cd}$ & $\mathrm{Zn}$ \\
\hline & & $\mathrm{mg} / \mathrm{kg}$ & $\mathrm{mg} / \mathrm{kg}$ & $\mathrm{mg} / \mathrm{kg}$ & $\mathrm{mg} / \mathrm{kg}$ \\
\hline Niubahuang & 7.82 & $\begin{array}{c}6091.74 \pm 580 \\
72\end{array}$ & $\begin{array}{c}2836.11 \pm 994 . \\
66\end{array}$ & $24.14 \pm 12.86$ & $\begin{array}{c}2514.65 \pm 601 \\
63\end{array}$ \\
\hline Kafang & 7.61 & $\begin{array}{c}5410.82 \pm 1109 \\
.63\end{array}$ & $\begin{array}{c}1572.44 \pm 792 \\
01\end{array}$ & $15.84 \pm 9.80$ & $\begin{array}{c}2626.48 \pm 1280 \\
.78\end{array}$ \\
\hline Southern & 7.68 & $\begin{array}{c}5699.05 \pm 1875 \\
.75\end{array}$ & $\begin{array}{c}1485.87 \pm 832 \\
11\end{array}$ & $11.10 \pm 7.55$ & $\begin{array}{c}1611.26 \pm 180 \\
33\end{array}$ \\
\hline $\begin{array}{l}\text { Soil environmental } \\
\text { background level in } \\
\text { Yunan Province }\end{array}$ & l & 515 & 28.7 & 0.083 & 86.0 \\
\hline $\begin{array}{l}\text { National soil environ- } \\
\text { mental quality III stan- } \\
\text { dard }\end{array}$ & / & l & 400.00 & 1.00 .00 & 500.00 \\
\hline
\end{tabular}

\section{Determination of samples}

The soil $\mathrm{pH}$ were determined in accordance with the "Soil Agrochemical analysis" method, by the method of 1:2.5 for soil and water ratio determination.

Nitric acid, hydrochloric acid -perchloric digestion, atomic spectrophotometer were used for the determination of heavy metal $\mathrm{Mn}, \mathrm{Cu}, \mathrm{Cd}, \mathrm{Zn}$, in soil.

Nitric acid and perchloric acid digestion of preparation to be checked, atomic spectrophotometer were used for the determination of heavy metal $\mathrm{Mn}, \mathrm{Cu}, \mathrm{Cd}, \mathrm{Zn}$, in plant.

\section{RESEARCH RESULTS AND ANALYSIS}

\section{Heavy metal content in mining wasteland soil}

The results of soil $\mathrm{pH}$ determination showed that the soil $\mathrm{pH}$ of wastelands soil were more than 7.5( neutral soil when $\mathrm{pH}$ was 6.5 to 7.5 ), for alkaline soil, which showed that the soil no acidification occurs. From table1, it can be seen that the contents of heavy metals in three mining wastelands more significant difference, and the contents of heavy metals $\mathrm{Mn}, \mathrm{Cu}$ and $\mathrm{Cd}$ in Niubahuang wasteland were significantly higher than the Kafang and the Southern, the content of $\mathrm{Zn}$ in the Kafang $>$ the Niubahuang $>$ the Southern. On the whole, the contents of heavy metals $\mathrm{Mn}>\mathrm{Zn}>\mathrm{Cu}>\mathrm{Cd}$, and the average contents of 4 kinds of heavy metals were $5733.87 \mathrm{mg} / \mathrm{kg}, 2250.80 \mathrm{mg} / \mathrm{kg}$, $1974.81 \mathrm{mg} / \mathrm{kg}$ and $17.03 \mathrm{mg} / \mathrm{kg}$, compared with the soil environment background level of Yunnan province(Liu and Ma2010), the average contents of $\mathrm{Cd}, \mathrm{Cu}, \mathrm{Zn}$ and $\mathrm{Mn}$ were higher than 11.13, 26.17, 68.81 and 205.51 in the Tin wastelands of Gejiu, and compared with the national soil environment quality grade three standard(Fan2011), the soil of $\mathrm{Zn}, \mathrm{Cd}$ and $\mathrm{Cu}$ average contents higher than $4.94,17.03$ and 4.50 .

An excess of heavy metal ions in soil great harm to plants, and the tolerance of plants is a key factor when remediating heavy metal polluted soil. In general, when the soil Cd content of $3 \sim 8 \mathrm{mg} / \mathrm{kg}, \mathrm{Pb}$ content of $100 \sim 400 \mathrm{mg} / \mathrm{kg}$, Zn content of $70 \sim 400 \mathrm{mg} / \mathrm{kg}$, Cu content of $150 \sim 400 \mathrm{mg} / \mathrm{kg}$ (total) is considered to produce toxicity to plants(Chen2013).

\section{Composition of plants}

Heavy metals in the soil for plants is a stress factors, especially in metal mining area, the shortage of nutrient, poor matrix structure, and high heavy metal content characteristics, the production of on plant growth stress or inhibition. Under normal circumstances, only a few highly tolerant plants on which to settle, the most of these plants have a special mechanism have adapted to their growth environment, special tolerance mechanisms of formation, has stronger resistance and adaptability for 
the harsh environment. They were usually dominated by herbs, shrubs and arbors occasionally settled, which may be related to herbs were more likely to form heavy metal tolerance.

The tin mining wasteland vegetation of Gejiu is domi nated by herb plants, accord with the characteristics of mine vegetation. This study collected plant spe cies was less, only 12 species, belonging to 8 families, 4 kinds of compositae, polygonaceae and pteridaceae families each 2 kinds, collected plants were mostly with herb plants was given priority to, which may be relevant to the characteristics and herb plants grow quickly, barren resistance, etc. The collection of the dominant plant species was shown in Table 2.

Table2 The plant samples genus name of wastelands

\begin{tabular}{cc}
\hline Family & Species \\
\hline Polygona- & Polygonum hydropiper $\mathrm{L}$. \\
Pteridaceae & $\begin{array}{c}\text { Polygonum } \text { capitatum } \\
\text { Hippochaete debilis } \\
\text { Pteris } \text { wallichiana }\end{array}$ \\
Gramineae & Phragmites australis \\
Ranuncula- & Thalictrum minus \\
ceae & var.hypoleucum \\
Solanaceae & Solanum tuberosum $\mathrm{L}$. \\
& Eupatorium adenophorum \\
Composotae & Galinsoga parviflora \\
& Erigeron acer \\
Coriariaceae & Artemisia carvifolia Buch. \\
\hline
\end{tabular}


Table3 The dominant plants of heavy metals content of wasteland

\begin{tabular}{|c|c|c|c|c|c|c|}
\hline \multirow{2}{*}{$\begin{array}{l}\text { Mining } \\
\text { wasteland }\end{array}$} & \multirow{2}{*}{ The sample name } & \multirow{2}{*}{ parts } & $\mathrm{Mn}$ & $\mathrm{Cu}$ & $\mathrm{Cd}$ & $\mathrm{Zn}$ \\
\hline & & & $\mathrm{mg} / \mathrm{kg}$ & $\mathrm{mg} / \mathrm{kg}$ & $\mathrm{mg} / \mathrm{kg}$ & $\mathrm{mg} / \mathrm{kg}$ \\
\hline \multirow{12}{*}{$\begin{array}{l}\text { Niuba- } \\
\text { huang }\end{array}$} & \multirow[t]{2}{*}{ Polygonum hydropiper L. } & $\begin{array}{l}\text { Aboveground } \\
\text { part }\end{array}$ & 533.62 & 415.88 & 6.16 & 173.85 \\
\hline & & root & 809.16 & 377.621 & 13.05 & 390.51 \\
\hline & \multirow[t]{2}{*}{ Coriaria nepalensis } & $\begin{array}{l}\text { Aboveground } \\
\text { part }\end{array}$ & 1292.16 & 70.65 & 3.93 & 190.41 \\
\hline & & root & 1438.90 & 93.04 & 6.21 & 642.36 \\
\hline & \multirow{2}{*}{ Polygonum capitatum } & $\begin{array}{l}\text { Aboveground } \\
\text { part }\end{array}$ & 2883.76 & 959.60 & 7.06 & 651.33 \\
\hline & & root & 1941.68 & 1203.31 & 11.79 & 537.48 \\
\hline & \multirow[t]{2}{*}{ Hippochaete debilis } & $\begin{array}{c}\text { Aboveground } \\
\text { part }\end{array}$ & 957.28 & 333.71 & 10.59 & 429.50 \\
\hline & & root & 4445.00 & 1835.29 & 8.67 & 288.39 \\
\hline & \multirow{2}{*}{ Phragmites australis } & $\begin{array}{c}\text { Aboveground } \\
\text { part }\end{array}$ & 515.68 & 87.17 & 4.51 & 326.34 \\
\hline & & root & 907.03 & 229.57 & 5.40 & 409.83 \\
\hline & \multirow{2}{*}{$\begin{array}{l}\text { Eupatorium } \\
\text { Spreng(1) }\end{array}$} & $\begin{array}{l}\text { Aboveground } \\
\text { part }\end{array}$ & 1022.19 & 99.13 & 3.26 & 166.26 \\
\hline & & root & 1383.70 & 174.60 & 5.27 & 237.33 \\
\hline \multirow{6}{*}{ Kafang } & \multirow[t]{2}{*}{ Erigeron acer } & $\begin{array}{l}\text { Aboveground } \\
\text { part }\end{array}$ & 1159.72 & 98.48 & 6.74 & 173.85 \\
\hline & & root & 2334.06 & 314.79 & 12.78 & 340.14 \\
\hline & \multirow[t]{2}{*}{ Artemisia carvifolia Buch. } & $\begin{array}{l}\text { Aboveground } \\
\text { part }\end{array}$ & 209.32 & 85.52 & 4.55 & 254.58 \\
\hline & & root & 1023.98 & 138.05 & 12.55 & 278.73 \\
\hline & \multirow{2}{*}{$\begin{array}{l}\text { Eupatorium } \\
\text { Spreng(2) }\end{array}$} & $\begin{array}{l}\text { Aboveground } \\
\text { part }\end{array}$ & 1092.06 & 90.00 & 7.39 & 300.12 \\
\hline & & root & 2253.56 & 140.22 & 12.87 & 272.52 \\
\hline \multirow{8}{*}{ Southern } & \multirow{2}{*}{$\begin{array}{l}\text { Thalictrum } \\
\text { var.hypoleucum }\end{array}$} & $\begin{array}{l}\text { Aboveground } \\
\text { part }\end{array}$ & 173.90 & 93.04 & 9.22 & 214.22 \\
\hline & & root & 2248.96 & 317.18 & 21.07 & 543.00 \\
\hline & \multirow[t]{2}{*}{ Solanum tuberosum L. } & $\begin{array}{c}\text { Aboveground } \\
\text { part }\end{array}$ & 351.46 & 86.52 & 9.76 & 465.03 \\
\hline & & root & 816.98 & 84.13 & 2.72 & 830.73 \\
\hline & \multirow[t]{2}{*}{ Pteris wallichiana } & $\begin{array}{c}\text { Aboveground } \\
\text { part }\end{array}$ & 350.08 & 87.83 & 5.27 & 445.71 \\
\hline & & root & 1261.34 & 254.36 & 5.18 & 251.82 \\
\hline & \multirow{2}{*}{ Galinsoga parviflora } & $\begin{array}{c}\text { Aboveground } \\
\text { part }\end{array}$ & 448.06 & 82.17 & 7.95 & 201.45 \\
\hline & & root & 935.20 & 425.88 & 5.54 & 492.63 \\
\hline
\end{tabular}

\section{The contents of heavy metals in each part of dominant plants}

The 12 dominant plants contents of heavy metals in tin mining wastelands in table 3 . From table 3 , the contents of heavy metals in plants and the contents of heavy metals in soil were basically consistent, reflected the heavy metal enrichment characteristic of plants exist a positive correlation with the contents of heavy metals in soil, the accumulation contents of heavy metals in plant increased with increasing of the content of heavy metals in soil, it consistented with the result of Yang Shengxiang, He Dong, et al. Overall, the absorption and enrichment characteristics of heavy metals in different plants showed a greater difference. 
In terms of $\mathrm{Mn}$ accumulation in plants, the highest content of Hippochaete debilis, $5402.28 \mathrm{mg} / \mathrm{kg}$, the lowest content of Solanum tuberosum L. Was $1168.44 \mathrm{mg} / \mathrm{kg}$, and the accumulation of Cd in plants, the highest content of Thalictrum minus var.hypoleucum, $30.83 \mathrm{mg} / \mathrm{kg}$, the lowest content of Eupatorium adenophorum Spreng (1), $8.53 \mathrm{mg} / \mathrm{kg}$. Typically, the normal content of heavy metals in plants: Mn 20 400mg/kg, Cu 0.4 45.8mg/kg, Cd 0.2 3mg/kg, Zn 1 160mg/kg. In this study, in 12 kinds of dominant plants, the $\mathrm{Mn}$ content of Polygonum capitatum aboveground up to $2883.76 \mathrm{mg} / \mathrm{kg}$, more than 7 times the normal content of the highest level of plant. Besides, Coriaria nepalensis, Eupatorium adenophorum and Spreng, Erigeron acer, the three plants aboveground and ground contents of $\mathrm{Mn}$ were higher than $1000 \mathrm{mg} / \mathrm{kg}$, indicating these four plants of $\mathrm{Mn}$ has stronger ability of enrichment. The content of $\mathrm{Cu}$ in the range of $70.65 \sim 1853.29 \mathrm{mg} / \mathrm{kg}$ in plants, the highest of which Hippochaete debilis, was 40 times the normal level. The content of $\mathrm{Cd}$ in plants was $2.72 \sim 21.07 \mathrm{mg} / \mathrm{kg}$, which is $0.91 \sim 7.02$ times higher than the normal highest level. The content of $\mathrm{Zn}$ in plants was $166.26 \sim 830.73 \mathrm{mg} / \mathrm{kg}$, which is $1.04 \sim 5.19$ times higher than the normal highest level.

\section{The transfer and enrichment characteristics of heavy metal in dominant plants}

BCF (bioaccumulation factor) was the ratio of the content of heavy metal in plant shoots and the corresponding content of heavy metal in soil, used to measure theplant on the absorption ability and accumulation ability of heavy metals in soil. BCF greater, indicating that its accumulation ability of heavy metal was stronger. From table 4, we can see that the BCF value of 12 kinds of dominant plants were less than 1, only Polygonum capitatum and Equisetum BCF of heavy metals were relatively large, indicating that these plants accumulation ability of heavy metal elements were weak.

BTF (Biological Transfer Factor) was the ratio of the content of heavy metals of aboveground and underground part in plant, used to measure the transfer ability of plant to heavy metals. BTF greater, suggested that the plant will divert heavy metals from the roots to shoots was stronger, that is, the tolerance of plant to heavy metal was stronger. The table 4 shows that in the 12 kinds of dominant plant, only the BTF of Polygonum capitatum to Mn was greater than 1, the BTF of Polygonum hydropiper and Solanum tuberosum to $\mathrm{Cu}$ were 1.10 and 1.03, the BTF of Hippochaete debilis, Solanum tuberosum and Galinsoga parviflora were greater than 1, especially Solanum tuberosum, its BTF to Cd was as high as 3.59, the BTF of Polygonum capitatum, Hippochaete debilis, Eupatorium

Table4 The BAF of heavy metals for plants of wasteland

\begin{tabular}{|c|c|c|c|c|c|c|c|c|c|}
\hline \multirow{2}{*}{$\begin{array}{c}\text { Mining } \\
\text { wastel- } \\
\text { ands }\end{array}$} & \multirow{2}{*}{ The sample name } & \multicolumn{2}{|c|}{$\mathrm{Mn}$} & \multicolumn{2}{|c|}{$\mathrm{Cu}$} & \multicolumn{2}{|c|}{$\mathrm{Cd}$} & \multicolumn{2}{|c|}{$\mathrm{Zn}$} \\
\hline & & $\mathrm{BCF}$ & BTF & $\mathrm{BCF}$ & BTF & $\mathrm{BCF}$ & BTF & $\mathrm{BCF}$ & BTF \\
\hline \multirow{6}{*}{$\begin{array}{l}\text { Niuba- } \\
\text { huang }\end{array}$} & Polygonum hydropiper L. & 0.09 & 0.66 & 0.15 & 1.10 & 0.25 & 0.47 & 0.07 & 0.45 \\
\hline & Coriaria nepalensis & 0.21 & 0.90 & 0.02 & 0.76 & 0.16 & 0.63 & 0.08 & 0.30 \\
\hline & Polygonum capitatum & 0.47 & 1.49 & 0.34 & 0.80 & 0.29 & 0.60 & 0.26 & 1.21 \\
\hline & Hippochaete debilis & 0.16 & 0.22 & 0.12 & 0.18 & 0.44 & 1.22 & 0.17 & 1.49 \\
\hline & Phragmites australis & 0.08 & 0.57 & 0.03 & 0.38 & 0.19 & 0.84 & 0.13 & 0.80 \\
\hline & Eupatorium adenophorum & 0.17 & 0.74 & 0.03 & 0.57 & 0.14 & 0.62 & 0.07 & 0.70 \\
\hline \multirow{4}{*}{ Kafang } & Erigeron acer & 0.19 & 0.50 & 0.03 & 0.31 & 0.28 & 0.53 & 0.07 & 0.51 \\
\hline & Artemisia carvifolia Buch. & 0.03 & 0.20 & 0.03 & 0.62 & 0.19 & 0.36 & 0.10 & 0.91 \\
\hline & adenophorum & 0.18 & 0.48 & 0.03 & 0.64 & 0.31 & 0.57 & 0.12 & 1.10 \\
\hline & Thalictrum & 0.03 & 0.08 & 0.03 & 0.29 & 0.38 & 0.44 & 0.09 & 0.39 \\
\hline \multirow{3}{*}{ Southern } & Solanum tuberosum L. & 0.06 & 0.43 & 0.03 & 1.03 & 0.40 & 3.59 & 0.18 & 0.56 \\
\hline & Pteris wallichiana & 0.06 & 0.28 & 0.03 & 0.35 & 0.22 & 1.02 & 0.17 & 1.77 \\
\hline & Galinsoga parviflora & 0.07 & 0.48 & 0.03 & 0.19 & 0.33 & 1.44 & 0.08 & 0.41 \\
\hline
\end{tabular}


adenophorum Spreng and Pteris wallichiana to $\mathrm{Zn}$ were greater than 1 . Therefore, the five native plants (Polygonum capitatum, Hippochaete debilis, Solanum tuberosum, Polygonum hydropiper an$\mathrm{d}$ Eupatorium adenophorum Spreng) can be chosen in the tin mining wasteland as tolerant plant.

\section{DISCUSSION}

Mine wasteland is a product of mining industry, with the increase of the number of its, it has become a global problem. Therefore, as soon as possible to the vegetation reconstruction in order to reduce the environment pollution of heavy metal in mining area, was the best strategy for mining area ecological restoration. However, these factors ,such as, poor soil structure, the shortage of nutrient, high heavy metal content, etc., limited the natural settlement of plants in mining wastelands. Nevertheless, there were still some plants (such as super accumulation plant) can complete their life history in the contaminated soil of high concentration of heavy metal, this indicates that the plant itself has a series of physiological and biochemical reaction in the long-tern natural evolution, for absorption and accumulation of heavy metal to form a series mechanism, such as suitable growth, resistance, tolerance and detoxification mechanism, adapted to the environment. Therefore, the 12 kinds of dominant plant can be used as the phytoremediation resources in tin mining wasteland. In addition, in 12 kinds of dominant plant, herbaceous plant accounted for the majority of the all, suggested that herbaceous plant has a strong ability to adapt the harsh environment of the tin mining wasteland.

Hyperaccumulator was a kind of plant, which refered to excessively absorb of heavy metals and constantly transfer its to the aboveground of plant. At present, the definition of hyperaccumulator mainly reference to Baker and Brooks proposed reference value in 1983, there are 3 basic characteristics. (1) the critical characteristics of content, namely, the critical content of accumulation of heavy metals in stems and leaves of plant, respectively, $\mathrm{Mn}$ and $\mathrm{Zn}$ were $10000 \mathrm{mg} / \mathrm{kg}, \mathrm{Cu}$ was $1000 \mathrm{mg} / \mathrm{kg}$ and $\mathrm{Cd}$ was $100 \mathrm{mg} / \mathrm{kg}$, or 10 to 100 times of the common plant without pollution. (2) transfer characteristics, that was, the content of heavy metal in the aboveground of plant were greater than the content of heavy metal in the root of plant. (3) grow well, no obvious toxic symptom, that was, with a certain ability of tolerance. In the 12 kinds of dominant plant, only the contents of polygonum capitatum and Hippochaete debilis reached to the $\mathrm{Cu}$ hyperaccumulator critical content standards. At the same time, they also showed a certain tolerance and absorption ability of heavy metals. These plants can adapt to the special environment of the mining area, which have the characteristics of tolerance barren and heavy metal stress. If these plants were planted in early stage of ecology restoration, they could increase vegetation coverage, improving soil surrounding and they could be pioneer plants in ecology restoring of the tin mining wasteland.

\section{CONCLUSION}

The results showed that the wasteland soil $\mathrm{pH}$ were more than 7.5 , for alkaline soil. On the whole, the contents of heavy metals $\mathrm{Mn}>\mathrm{Zn}>\mathrm{Cu}>\mathrm{Cd}$, and the average contents of 4 kinds of heavy metals were $5733.87 \mathrm{mg} / \mathrm{kg}, 2250.80 \mathrm{mg} / \mathrm{kg}, 1974.81 \mathrm{mg} / \mathrm{kg}$ and $17.03 \mathrm{mg} / \mathrm{kg}$.

This study collected plant species was less, only 12 species, belonging to 8 families, 4 kinds of compositae, polygonaceae and pteridaceae families each 2 kinds, most of collected plants were herbaceous plants. The accumulation contents of heavy metals in plant increased with increasing of the content of heavy metals in soil, the contents of heavy metals in most plants were higher than the normal contents of general plants.

The study collected 12 kinds of dominant plant, the BCF of plants were less than 1, only the BCF of polygonum capitatum and Hippochaete debilis to heavy metals were relatively large. From the BTF, the BTF of polygonum capitatum and Hippochaete debilis respectively to two kinds of heavy metals were greater than 1. Therefore, the two native plants such as, polygonum capitatum and Hippochaete debilis can be chosen in the tin mining wasteland as tolerant plants. 


\section{REFERENCES:}

[1] Yang Jian, Chen Jia-jun, Wang Xin-yi. Spatial distribution of heavy metals in soils around the coal waste rock pile and their environmental pollution assessment[J].Journal of agro-environment science, 2008, 27(3):873-878.

[2] Yue Qing-ling. Study on heavy metal of soils and plants in mining in $\mathrm{Hu} \mathrm{Nan}[\mathrm{D}]$.Yangling, Northwest Agriculture and Forestry University,2004.

[3] China Environmental Protection Agency. China ecological problem report[M].China Environmental Science Press,2000.

[4] Bradshaw A D. Restoration of mined lands-using natural process[J].Eco Eng,1997,8:255-269.

[5] Gan Feng-wei, Fang Wei-xuan, Wang Xun-lian,et al. The heavy metal contamination in soilpotato and pea of tin tailings[J].Ecology and Environmental Science,2008,17(5):1847-1852.

[6] Zhang Zheng-hai, Fang Xiang-jing, Meng Guang-tao, et al. Preliminary study on the control system of non-point source pollution in abandoned lands of mining area[J].Journal of Anhui Agri. Sci, 2010,38(16):8622-8623,8649.

[7] Liu Feng-zhi, Ma Jin-qiu. Practical handbook of soil monitoring and analysis[M].Chemical Industry Press,2010.

[8] Fan Shuan-xi. Soil heavy metal pollution and control[M].China Environmental Science Press, 2011.

[9] Chen San-xiong, Liao Jian-wen, Yang Qun-liang,et al. Heavy metal accumulation characteristics of plants in Dabaoshan mine in Guangdong Province[J].Pearl river , 2013,3:18-22,30. 